\title{
L'ESGLÉSIA SECULAR CATALANA AL SEGLE XIV: LA CONFLICTIVA RELACIÓ SOCIAL
}

FlOCEL SABATÉ

Universitat de Lleida

\begin{abstract}
SUMARI
1. Les tensions urbanes: jurisdicció, fiscalitat i tonsura.- 2. L agressivitat rural. - 3. La difícil delimitació dels ambits jurisdiccionals.- 4. Escrivanies $i$ oficis reials vedats.- 5. Discurs $i$ armes de l'Església. - 6. El conflicte de les temporalitats. - 7. Relacions a la cúpulat del poder. -8 Vers l'anticlericalisme popular'.
\end{abstract}

La dualitat presideix la relació de l'Església secular amb la societat baixmedieval: condemna la usura alhora que té en els seus clergues uns dels principals abastidors de crèdit, especialment en els àmbits rurals; exigeix el respecte a la pròpia jurisdicció mentre dins d'aquesta inclou clergues conjugats que duen vida laica; gaudeix dels avantantges de la vida urbana

\footnotetext{
'Abreviatures emprades: ACA. Arxiu de la Corona d'Aragó: ACV. Arxiu Capitular de Vic: ADG. Arxiu Diocesà de Girona: ADM. Archivo Ducal de Medinaceli: ADPO. Archives Departementales des Pyrénées-Orientales: AEV. Arxiu Episcopal de Vic: AHCBI. Arxiu Historic Comarcal de Balaguer: AHCBr. Arxiu Historric de la Ciutat de Barcelona: AHCG Arxiu Historic de la Ciutat de Girona: AIICM. Arxiu Historic de la Ciutat de Manresal AHCO. Arxiu Ilistoric Comarcal d'Olot: AIICP. Arxiu Historic Comarcal de Puigcerda: AHCR. Arxiu Ilistoric Comarcal de Reus: AHCT. Arxiu Historic Comarcal de Tarrega: AHCTE Arxiu Ilistoric Comarcal de les Terres de l'Ehre: AHCV. Arxiu Historic Comarcal de Valls AHMTM. Arxiu Historic Municipal de Torroella de Montgrí; AHMV. Arxiu Hlistoric Municipal de Vic: AHPB. Arxiu Historric de Protocols de Barcelona; AHT. Arxiu Historic de Tarragona: AML. Arxiu Municipal de Lleida: AMSJA. Arxiu del Monestir de Sant Joan de les Abadesses: APSMM, Arxiu Parroguial de Santa Maria del Mar: AVV. Arxiu del Veguer de Vic; BC. Arxiu de la Bibliotecal de Catalunyat.

"Anuariu de lestudios Medicvales". 28 (1998)
} 
però pretén no contribuir-hi fiscalment o jurisdiccionalment. Són contradiccions que no poden menys que menar a situacions de gran tensió, entorn a les quals tothom es posicionarà: el poder vilatà exigint una participació en els costos municipals i vetllant per l'exercici jurisdiccional; l'Església amb l'articulació del discurs defensiu jurídic i espiritual; el sobirà formulant l'enlairament de la monarquia en el joc del poder; i el poble elaborant un específic raonament anticlerical.

\section{LES TENSIONS URBANES: JURISDICCIÓ, FISCALITAT I TONSURA}

El col-lectiu eclesiàstic gaudeix de la consideració estamental particular, cosa que l'eximeix de l'exercici jurisdiccional i del tractament legislatiu pertanyent als diferents nuclis vilatans. La lògica jurídica permet als clergues beneficiar-se dels avantatges urbans com habitadors sense participar en els seus costos fiscals ni en les seves responsabilitats jurisdiccionals. Els governs locals invocaran l'aparent paradoxa i exigiran una participació que serà rebutjada per l'Església ordinària, contrarietat que mena a tensions, proporcionalment creixents amb les dificultats financeres $i$ d'ordre públic que es van apoderant de la centúria, sobretot traspassat mitjan segle.

Les discrepàncies sorgeixen, a nivell fiscal, tant en la redacció del manifest com en la recaptació de talles i imposicions o en la contribució en remissions, treves i paus, per considerar l'Església que el clergue mai "no ha contribuit en taylles, ajudes ne altres negocis, segons que los altres ciutadans fan"2. En sentir-se fiscalment exempts, també es negaran a contribuir en les costoses despeses de reparació i construcció de muralles que carreguen tots els municipis a la segona meitat del segle XIV, fins i tot quan, com a la Girona de 1332, els seus habitatges sobre el mur són assenyalats per la població com els responsables que les defenses estiguin trocades $e$ destroydes $^{3}$. La mateixa exempció empara l'entrada de productes a la vila en contra no sols de les percepcions obligades sinó de les limitacions imposades, amb tibantors ben enquistades entorn al vi, del que molts

\footnotetext{
'AHMV Llibre de Privilegis II, pergamí 34.
}

'AHCG 1.1.2.1, lligall 1, llibre 2, fol. 26v. 
clergues són acusats d'esdevenir-ne il-lícits revenedors després d'entrar-lo a la vila en contra de les vedes. A nivell jurisdiccional, les alteracions d'ordre, sobretot per raó de la col·lisió de bàndols ${ }^{4}$, comporten una barreja estamental arran de "sediciones ac tumultus" amb mescla de violències "tam contra clericos quod alias personas" ${ }^{5}$, en les que els eclesiàstics s'esmunyiran de la justícia ordinària per la seva condició personal.

Les discrepàncies s'agreugen entorn del nombrós conjunt de "clergues conjugats", conformat per homes que duen una vida laica en tots els aspectes però que són de jurisdicció eclesiàstica per haver rebut la tonsura - "clericus simplex tonsuratus" - ja sigui en la infantesa - l'atorga el bisbe durant les visites pastorals a nens suposadament preparats per la parròquia $-\mathrm{o}$ en algun altre moment de la seva vida. Moltes vegades es desconeix la condició clerical fins que el propi afectat la invoca a manera de garantia d'impunitat. Aleshores es repeteixen fets com el viscut a Girona el 1335, quan el batlle després de retenir l'espasa d'un home que circulava per la nit armat i sense llum, és comminat pel vicari episcopal a retornar l'arma i descarregar de càrrecs l'afectat en tractar-se d'un clergue conjugat? D'aquesta manera, nombrosos incompliments de bans resten impunits arreu. Igualment, esdevé estèril l'actuació de l'oficial ordinari en pretendre procedir per l'incompliment de deutes i contractes registrats en la cort ordinària, raó per la que el govern municipal de Barcelona el 1397 elevarà les protestes al Papa $^{x}$. La mateixa impunitat dels clergues conjugats s'estén sobre les contribucions fiscals, fins i tot amb el frau de declarar els propis béns com a propietat d'algun familiar que ha rebut la tonsura. El govern local de Montblanc no s'està d'acusar "que en la dita vila ha alguns singulars qui han

\footnotetext{
${ }^{4} \mathrm{AHCT}$, pergamins, caixa 10, 1376.

${ }^{5} \mathrm{ACV}$. calaix 37. Privilegis i Estatuts IV. pergami 73.

"Josep M. MARTI I BONET: Leandre NiQUI I PUIGVERT. Els processos de les visites pastorals del primer any del pontificat de Ponc de Gualba (a. 1303). "Processos de l'Arxiu Diocesa de Barcelona". I. Departament de Cultura de la Generalitat de Catalunya, Barcelona, 1984. pp. 25 27: Pere Benito. Les parròquies del Maresme a la baixa edat mitjana. Una aproximació des de les Visites Pastorals (1305-1447). Caixa d'Estalvis Laietana. Mataró, 1992. pp. 130-132.

${ }^{7}$ AIICG I.1.1.2.1, Iligall 2. Ilibre 2, fol. 29v.

${ }^{8}$ Atès que. "alegrant-se de privilegis clericals". s"està anant "contra Déu i justicia e en gran frau d"aquelles persones qui ah ells contracten" (AHCBr. Fons municipal B-I. llibre 27, fol. $70 v)$
} 
emancipat lurs fills et donat tot quant havien et han los feta corona", eludint així de pagar "la questa de la dita vila"9.

A la impunitat s'afegeix la intranquil-litat infosa a uns oficials ordinaris reiteradament acusats per haver procedit contra clergues, i no poques vegades afectats per les discussions amb els homòlegs episcopals per escatir qui gaudeix de la condició de clergue, incloent consultes per saber què consta "scriptum in libro Curie Decani"10.

La jurisdicció eclesiàstica esdevé objecte de la permanent malfiança de les institucions municipals i jurisdiccionals". Era "fama pública" que l'Església protegia així els qui "allegaven privilegi de clergue per què no poguessin ésser punits per los officials del senyor Rey"12, amb una proverbial impunitat reiterament retreta pels monarques ${ }^{13}$, convençuts que no és pas cap altra cosa el que cerquen els qui sols reben la simple tonsura ${ }^{14}$.

La mateixa autoritat eclesiàstica contribueix a aquesta situació en blindar jurisdiccionalment els propis partidaris mitjançant la concessió de tonsures, reforçant així l'entorn de força i atorgant un contingut específic als anomenats "familiars del bisbe" o, a Tarragona, "de l'arquebisbe" ${ }^{15}$. La tonsura esdevé, en si mateixa, un arma en el joc del poder, d'efectes equiparables als canvis de fur cada cop més emprats pel sobirà. En els conflictes de regalies succeeixen casos com els viscuts a Elna, on en imposar el rei la capacitat exclusiva sobre les aigües marines, en contra de les

"ACA. Cancelleria, reg. 2018, fol. 72r (ed.: Francisco de Bofarul. I Sans. Documentos para escribir una monografia de la villa de Montblanc. "Memorias de la Real Academia de Buenas Letras de Barcelona", VI [Barcelona. 1896], p. 507).

${ }^{10} \mathrm{ACA}$, Cancelleria, reg. 507, fol. 124r.

"AHCG 1.1.2.1, Iligall 1, llibre 2, fol. 99r-v.

"2AHMV, Ordinacions del Sr. Rey D. Alfonso sobre salaris de jutges, advocats y procuradors. fol. $4 \mathrm{v}$.

I:El 1318 Jaume II retreu al degà vigatà a l'Urgell que per "clericos comorantes in villa Tarrega plura vulnera, furta et alia enormia maleficia quotidie in dicto loco multipliciter comitur et quod lez querimonia coram vobis fieri prosperata de eiusdem nulla per vos sic punitio contra eos" (ACA, Cancelleria, reg. 245. fol. 18r).

HEl mateix Jaume II el 1314 raona que "hoc non fecerint nec faciant animo ad sacros ordines promovendi nec ut tenentur Divino Cultui insistendi, sed solum ut perpetratis per eos facinoribus, ex privilegiis cetui clericorum indultis, quibus gaudere non merentur, temporalis gladii poenam haberent materiam evitandi" (Pragmàticas y Altres Drets de Cathalumya, II, tit. V, cap. 2, ed. Constitucions y altres Drets de Cathalimya, Departament de Justicia de la Generalitat de Catalunya, Barcelona, 1995. Pragmàricas, p. 15).

${ }^{15}$ AHCR, pergamins, carpeta Cambrers 12, núm 19: 13, núm. 3. 
pretensions del bisbe, els infractors que haurien de ser punits pels oficials del monarca troben acollida en l'entorn episcopal, on se'ls ofereix la tonsura per tal de poder així defugir les demandes règies.

Tots els qui reclamen ésser tractats com tonsurats són exigits per l'autoritat eclesiàstica, que no renuncia a aquesta capacitat de penetració jurisdiccional. Per això, en una clima de forta tensió, desemboquen en greus enfrontaments entre jurisdiccions fets com el generat a Perpinyà quan l'oficial episcopal procedeix contra "los officials reyals, specialment lo batle de Perpenyà, per ço car tenia pres algun hom de Castella delat de la mort de sa muller qui.s apellava Diego, mer laych e taverner e qui tenia taffureria, e s'havia feta fer corona dins la presó, jatsia no fos del tot acabada e qui jamés no pot fer fer de títol algú car non havia"16.

Jaume II i Alfons III lamentaran l'aparent impunitat i exhortaran els seus oficials, davant de casos concrets, a intervenir-hi, cosa, però, que propiciarà importants queixes eclesiàstiques. Pere III, el 1359, proposa que, en situacions flagrants, els oficials ordinaris puguin detenir els clergues "in locis inhonesti vel ritxam moventibus" per a lliurar-los després a la cort episcopal ${ }^{17}$, pretensió, però, també desbatarada pel poder episcopal. Joan I aconseguirà de Benet XIII autorització per a perseguir els clergues acusats per deutes, bé que a la pràctica costa molt d'aplicar i en el segle XV caldrà continuar-hi insistint ${ }^{18}$. Amb normalitat, sols al bisbat d'Elna poden actuar comissaris reials sobre clergues, tant per a procedir sobre els qui afegeixen el tractament de familiars del rei com per a completar les indagacions respecte de la seva moralitat.

La monarquia anima els municipis en els enfrontaments amb els col-lectius eclesiàstics, intercedint-hi -com exposa el 1355 davant de l'arquebisbe de Tarragona en la qüestió del delme-, pronunciant-s'hi a favor - com a Barcelona el 1362 entorn de l'ajuda del vi $\mathrm{i}^{19}$ - i fins i tot amenaçant els clergues, com fa Pere III el 1366 a Girona en manar que els oficials reials "sense altra tarda vos en forçen e destreuguen" o, com pretén l'infant Joan el 1378 a Besalú, decretant presó per als eclesiàstics que no vulguin contribuir. La manca de voluntat a col-laborar en les despeses dels

\footnotetext{
${ }^{16} \mathrm{ADPO}$ 1B-346, fol 170r.

${ }^{17} \mathrm{AHCBr} \mathrm{C}-\mathrm{V}$, caixa 1, plec "contra tonsuratos et personas eclesiasticas", sense numerar. ${ }^{18} \mathrm{ADPO}$ IB-346, fols. 155v-156r

"AHCBr, C-V, caixa 1. plec "contra tonsuratos et personas ecclesiasticas", sense numerar.
} 
municipis és permanentment criticada per una corona reial que, erigida en "príncep e senyor e garde del bé de la cosa pública"20, pot considerar els clergues com "inimicos publicos"21 per no moure's "per lo bé de la cosa pública d'aquella ciutat e encar de totes ses comarques"22, per desatendre la tasca d'"officia celebrari"23 i per oblidar que "arma clericorum sunt lacrimis et orationes"24.

Per tal de diferenciar adientment els clergues conjugats, Jaume II reclama el cumpliment de les disposicions eclesiàstiques que els imposen "habitum et tonsuram"25 per a preservar la condició de tonsurats. Aleshores, però, els oficials reials poden ser sorpresos, com li succeix al veguer de Vic el 1383 en voler detenir un acusat de maltractar l'esposa i trobar-lo "in habitu clericali et tonsura"26, estratagema prou usual per a evitar que es pugui dir que "tempore capcionis non portabat tonsuram neque vestes clericales". Cercant la clarificació d'aquest panorama, des de 1314 la corona reial malda per delimitar el privilegi eclesiàstic mitjançant excloure'l als qui practiquen "officio mercature vel aliis artibus mecanicis", mesura inicialment assumida per la jerarquia eclesiàstica que, amb suport papal, decreta el registre dels clergues. L'immediat incompliment fa que Pere III no sols n'exigeixi l'aplicació el 1374 , tot recalcant les activitats impròpies d'un eclesiàstic ${ }^{27}$, sinó que reiteradament -1345, 1366 i 1386 sobretot- reclami la moralitat dels tonsurats. Tanmateix, el rei Martí, haurà de tornar a insistir-hi el 1407, reprenent els mots, ja pronunciats pel seu besavi el 1314, en la pretensió d'evitar que els tonsurats entrin en el món laboral urbà al manar que ningú no "gosàs tenir algun dexeble clergue o tonsura portant per apendre e usar de offici de mercaderia o quin d'aquell offici usàs"28.

\footnotetext{
${ }^{20}$ AHCG I.1.2.1, llgiall 6, llibre 1, fol. 187r-v.

${ }^{21} \mathrm{AHCO}$, Fons notarial. Secció Besalú, registre 285, sense numerar.

"2AHCG 1.1.2.1, lligall 6, llibre 1, fol. 187r-v.

${ }^{23} \mathrm{AHCBr}, \mathrm{C}-\mathrm{V}$, caixa 1, plec "contra tonsuratos et personas eclesiasticas", sense numerar. $22 \mathrm{v}$.

${ }^{24} \mathrm{AHCV}$, Administració de Justícia, Cort del batlle, processos 1391, sentència plet, fol.

${ }^{25}$ Johannes VINCKE, Documenta selecta mutuas civitatis arago-cathalaunicae et ecclesiae relationes illustrantia, Biblioteca Balmes, Barcelona, 1936, pp. 102-104, 126.

${ }^{26} \mathrm{AHMV}$, Llibre de Privilegis XXV, pergamí 434.

${ }^{27}$ Pragmaticas y Altres Drets de Cathalunya, II, tit. V, caps. 2-8 (Constitucions y altres Drets de Cathalunya, Departament de Justícia de la Generalitat de Catalunya, Barcelona, 1995. Pragmàticas, pp. 15-17).

${ }^{28} \mathrm{ADPO}$ 1B-346, fols. 71r, 77r-v.
} 
Alhora, els governs locals malden per desmuntar l'ambigüetat cercada pels clergues conjugats. A Lleida el 1340 s'adverteix que qui es declari clergue s'atingui a les conseqüències de perdre tots els beneficis propis de la condició ciutadana, incloent que "de continent li sien toltes totes mesures, pes e alna que tingue en lurs botigues ho obradors" ${ }^{29}$. De tota manera, la fractura interna en bàndols condiciona la clarificació a les conveniències i evolucions dels equilibris de poder, com prou significativament es viu a $\mathrm{Vic}^{30}$.

Mestrestant, tots els tonsurats pretenen seguir gaudint dels avantatges urbans i sols al-legen "beneficium clericale et tonsuram" en el moment de ser detinguts o fins $\mathrm{i}$ tot quan s'està donant compliment a la sentència, evitant aquesta en el darrer moment, tal com recull la literatura ${ }^{31}$ i com, de manera ben explícita, fa Francesc Alegre, el 1330 en advertir ésser "clericum tonsuratum" després d'haver estat jutjat i condemnat a "furca suspendendum" ${ }^{32}$,

El clergat secular, ben organitzat en les comunitats de preveres, amb el suport episcopal i amparat jurídicament, esdevé objecte de difícils negociacions per a uns governs locals que persegueixen la seva contribució fiscal, si més no pel que fa als clergues que sols gaudeixen d'ordres menors $i$, molt concretament, els conjugats, inclosos dins dels qui "faessen mercaderia" 33 . El manifest de béns -es tem que les donacions efectuades als clergues es fonguin fiscalment - i la participació en imposicions i talles s'aniran aconseguint localment amb dificultat mitjançant avinences i sentències arbitrals sargides d'apel-lacions $\mathrm{i}$ incompliments ${ }^{34}$.

Tot plegat propicia un clima molt tens, on la imatge de l'Església secular també és popularment danyada per les excessives exigències pels serveis litúrgics, a voltes dispensats amb recança i previ pacte amb el municipi, tot contrastant amb el posicionament dels mendicants, sempre més

\footnotetext{
2"AML, Secció de Consells municipals, A-396, fol. 92r.

${ }^{30}$ AHMV Llibre de Privilegis II, pergamí 34.

${ }^{31}$ Francesc de la VIA, El Llibre de Fra Bernat, ed. Laertes. Barcelona, 1989, p. 89.

${ }^{32} \mathrm{AHCV}$, pergamí 51 . $12 r$.

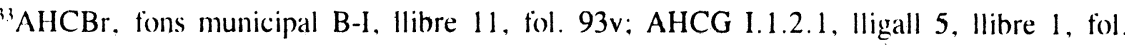

${ }^{3}$ Flocel SABATÉ, L'augment de l'exigència fiscal en els municipis catalans al segle XIV: elements de pressió $i$ de resposta, "Col-loqui Corona, Municipis i Fiscalitat a la Baixa Edat Mitjana (Lleida, 1995)". Institut d'Estudis Ilerdencs, Lleida, 1997, pp. 455-457.
} 
propers al tarannà municipal. Cal afegir-hi el ressò de tibantors pels dominis territorials de la mitra en la regió d'influència —com palmatòriament succeeix a Girona amb les discussions per la participació a les hosts ${ }^{35}-$, l'actuació creditícia de molts clergues i la imatge dissipada d'un col·lectiu amb moltes mancances de formació. A més, el poder local s'arrenglerà contra l'episcopat en temes doctrinals com la condició cristiana dels esclaus grecs o en la protecció de població vilatana i ciutadana perseguida per l'actuació inquisitorial contra l'heretgia. Per això costa tant posar-se d'acord per a preparar els funerals per la mort del rei ${ }^{36}$ i per això qualsevol espurna pot fer esclatar una revolta contra les persones i els béns de l'Església, com succeix a Barcelona el $1370^{37}$ o, molt més contundentment, a Elna, amb l'assalt al palau episcopal ${ }^{38}$.

$\mathrm{Cal}$, en certa manera, avesar-se, a la violència contra béns i persones de l'Església. Es reiteren robatoris en els principals temples de viles com Sant Joan de les Abadesses ${ }^{39}$ o Banyoles ${ }^{40}$ i és molt elevat el nombre de clergues no sols agredits sinó assassinats, com succeix el 1333 amb el degà de Manresa ${ }^{41}$ o com s'exposa el 1375 a les Corts respecte del canonge mort a l'església de Santa Eulàlia de Vic ${ }^{42}$. És, en aquest sentit, una agressivitat similar a la viscuda coetàniament en l'àmbit rural.

\section{L'AGRESSIVITAT RURAL}

L'espai rural, llargament avesat a diverses formes de violència contra les persones i el patrimoni eclesiàstic, contempla, en el segle XIV, diferents nivells d'agressió.

\footnotetext{
${ }^{35}$ AHCG I.1.2.1, lligall 1, llibre 3, fols. 27v-28r.

${ }^{36}$ Flocel SABATÉ, Lo senyor rei és mort, Edicions de la Universitat de Lleida, Lleida, 1994, pàgs. 159-172.

${ }^{37}$ Carme BATLle, Un exemple de la hipersensibilitat popular (Barcelona, Corpus, 1370), "VIII Congreso de Historia de la Corona de Aragón (Valencia, 1967)", II, Valencia, 1970, pp. 91-101.

${ }^{38}$ ADPO 1B-164, fol. 168r-v.

${ }^{39}$ AMSJA, Processos criminals 1300-1309, plec 1305, sense numerar.

${ }^{40}$ ACA, Reial Patrimoni, Mestre Racional, 1556, fol. 55r.

${ }^{4}$ ACA, Cancelleria, reg, 528, fol. 249r.

${ }^{42}$ Cortes de Cataluña, "Cortes de los antiguos reinos de Aragón y de Valencia y Principado de Cataluña", III, Real Academia de la Historia, Madrid, 1900, p. 308.
} 
Les discrepàncies jurisdiccionals mantenen unes divergències similars a les de qualsevol altre domini, amb invasions als oponents $\mathrm{i}$ amb conflictes per aspectes com els pasturatges o per qüestions de jurisdicció, a voltes amb molta tensión ${ }^{43}$. En aquest marc es produiran agressions a àmbits monacals, com en les tibantors entre Torroella de Montgrí i el cenobi d'Ullà ${ }^{44}$, i es repeteixen atacs protagonitzats per solidaritats municipals, com el greu assalt dels vigatans a la casa del monestir de Ripoll a Palau de Granollers ${ }^{45}$. Són actuacions que contribueixen a l'elevat percentatge d'agressions, sota diverses motivacions, a dominis monàstics, amb priors i abats nafrats o fins i tot assassinats ${ }^{46}$.

Es reiteren igualment els robatoris en els temples al llarg de tot el segle. Com en els espais vilatans, els principals objectes robats són robes i teles, seguides ben a prop per objectes litúrgics i, en tercer lloc, imatges i reretaules. Els oficials ordinaris han de procedir davant d'aquests casos, en vora la meitat dels quals s'atribueix la responsabilitat a un clergue.

A vegades, els eclesiàstics són assaltats en el camí, de manera no gaire destriable als ocasionals robatoris. Molt més freqüentment, es pretén agredir a clergues concrets, ja sigui per raó de bàndols, sovintejat per les interseccions amb les topades urbanes característiques de zones com l'entorn vigatà $^{47}$, o, encara en major nombre, per tensions relacionades amb qüestions creditícies. En tot el camp català el volum de clergues dedicats al crèdit és molt elevat. Les dificultats de la segona meitat de segle hi vinculen un elevat nombre de població, en ocasions debent amb gran dificultat molts diners. Alhora, els mateixos clergues també efectuen inversions associats amb laics, generant així nous lligams econòmics. Molts rectors rurals, mitjançant aquestes activitats, especulen amb les rendes de la parròquia,

\footnotetext{
${ }^{43}$ ACA, Reial Patrimoni, Mestre Racional 1524, fol. 250v; ACV, calaix 9, pergamins del bisbe Ponç de Vilaró, 1301.

${ }^{44}$ AHMTM, pergamí 40

${ }^{45}$ AHMV, llibre de Privilegis VIII, pergamí 155.

${ }^{{ }^{6}} \mathrm{No}$ sols fets de gran ressò, com l'assalt de Serrateix el 1251 (Joan SERRa VILARÓ, Història de Cardona, I, Imprenta Sugrañes, Tarragona, 1966, pp. 200-204) o l'assassinat de l'abat de Sant Cugat el 1350 (Cortes de Cataluña, "Cortes del Reino de Aragón y de Valencia y Principado de Cataluña". I Real Academia de la Historia, Madrid, 1896, pp. 386-387) sinó reiterats casos com l'anada del veguer de Rosselló el 1358 "al loch de Sant Nicholau per pendre confessió de l'abat de Valbona, lo qual trobaren naffrat" (ACA, Reial Patrimoni, Mestre Racional, 1522, fol. 346r).

${ }^{47}$ AHMV, llibre de Privilegis VII, pergami 25.
} 
establint fins i tot una amplia xarxa de deutors, com assoleix en l'antepenúltima dècada del segle l'osonenc rector de Sant Julià. A voltes són rectors que acumulen diverses prebendes i, encara més, que practiquen un absentisme que els converteix en veritables clergues rendistes urbans, pagant el vicari que desenvolupa les tasques pastorals. Precisament, molta gent de la ruralia contracta obligacions creditícies amb eclesiàstics residents en viles i ciutats, alguns força coneguts en el seu moment com, traspassat mitjan segle, Guillem Salomó a Vinçà o Jaume Vila a Perpinyà. Els endeutats assumeixen les obligacions creditícies obligant-se davant de la cort de l'oficial episcopal o de la jurisdicció ordinària, per tal de poder ser perseguits en cas d'incompliment, amb la corresponent demanda de la pena de terç.

En aquest context, la violència apareix en el doble vessant. Per un costat, nombrosos clergues són assenyalats com extorquidors de deutors ${ }^{48}$ $\mathrm{i}$ fins $\mathrm{i}$ tot alguns cauen sota sospita d'induir i excercir violències $\mathrm{i}$ assassinats $^{49}$. De forma encara més freqüent, els eclesiàstics són els agredits. Tant per tibantors de bàndol com per diferències generades entorn als crèdits, es reiteren atacs personals, intimidacions amb espasa o amb ballesta $\mathrm{i}$, en primer lloc, assalts a domicilis, que normalment comporten actuacions de saqueig, però també d'incendi i destrucciós ${ }^{50}$. Al llarg de la centúria, no sols la involucració dels clergues en els diferents actes de violència és constant ${ }^{51}$ sinó que un $12 \%$ dels assassinats els té per objecte, als que ocasionalment es pot afegir la mort de personal al seu servei ${ }^{52}$. En la seva punició s'hi compliquen els conflictes de jurisdicció territorial ${ }^{53} \mathrm{i}$ les interferències de bàndols ${ }^{54}$, alhora que el volum justifica el 1359 el guiatge reial sobre clergues atès que "diversa, enormia ac crudelia homicidia

\footnotetext{
${ }^{48}$ AVV, Processos civils 1350-1359, plec 1350-3, sense numerar.

${ }^{49} \mathrm{AVV}$, Processos criminals 11, plec 1388-2, sense numerar.

${ }^{50}$ ACA, Reial Patrimoni, Mestre Racional 1424, fol. 307r; ACA, Cancelleria, reg. 242, fol. 137r; AVV, Processos civils 1313-1317, plec 1316, sense numerar.

${ }^{51}$ ACA, Cancelleria, reg. 143, fol. 92v; reg. 250, fol. 18v; "Papeles por incorporar", Cervera, sense numerar; Reial Patrimoni, Mestre Racional, 1523, fol. 79v

${ }^{52}$ ACA, Reial Patrimoni, Mestre Racional 1524, fols. 270v, $281 \mathrm{r}$.

${ }^{53}$ Cortes de Cataluña, "Cortes de los antiguos reinos de Aragón y de Valencia y Principado de Cataluña", III, Real Academia de la Historia, Madrid, 1900, p. 308; ACA, Reial Patrimoni, Mestre Racional, 1426 C-1, sense numerar.

${ }^{54}$ ACA, Reial Patrimoni, Mestre Racional, 1524, fol. 250r.
} 
personarum religiosorum et ecclesiasticarum et etiam aliorum comissa fuerint et frequentes comittantur in Cathalonia"55.

\section{LA DIFÍCIL DELIMITACIÓ DELS ÀMBITS JURISDICCIONALS}

L'àmbit de la jurisdicció eclesiàstica es defineix amb nitidesa pel caire personal de l'inculpat: inclou tot aquell que sigui clergue. Per això, les agressions contra persones o béns de l'església i el respecte pels llocs sagrats, són tractats pels oficials ordinaris ${ }^{56}$, els quals, en canvi, es guarden d'intervenir si l'acusat és un clergue. Fins i tot inicialment quan es tracta d'incompliment de regalies, la jurisdicció reial cedeix l'inculpat a la jurisdicció eclesiàstica i s'haurà limitat només a detenir-lo i exhortar la seva punició, com sovinteja sota Jaume II $^{57}$. En barrejar-se laics i religiosos, com en les obligacions contretes en sentències arbitrals, cal, precisament, esmentar ambdues corts, la civil i l'eclesiàstica. Les pretensions reials per a practicar detencions, apuntades per Jaume II però reiterades per Pere III, sols es materialitzen de manera efectiva al Rosselló, per raó del peculiar equilibri jurisdiccional entre la puixant Perpinyà i l'esmicolament jurisdiccional, cosa que, traspassat mitjan segle, permetrà detenir clergues ${ }^{58}$, sobretot en ser acusats de trencament de pau i treva o d'incompliment de regalies ${ }^{59}$.

L'oferiment de la corona reial com a bracchium seculare és ocasionalment assumit per l'Església, al llarg de tot el segle, davant de problemes jurisdiccionals ${ }^{60}$ i com a reforç d'una força física absent en la institució eclesiàstica, segons es pacta a Vic el 1347, quan per a pacificar les tensions de bàndols s'especifica que l'Església actuarà "invocato ad hoc per

\footnotetext{
${ }^{55} \mathrm{AHCP}$, Provisions Reials 1.1, fol. 17v.

${ }^{56}$ El 1367 el veguer de Rosselló amonesta el batlle d'Elna tant per intervenir a Sant Llorenç com per fer-ho amb una detenció dins de l'església "non obstante quod missa maior celebraretur", és a dir, "turbando in hiis divinum officium" (ACA, Reial Patrimoni, Mestre Racional 1523 , fol. 10r)

${ }^{57} \mathrm{ACA}$, Cancelleria, regs. 235, fol. 212r; 239, fol. 96r; 244, fol. 17r; 247, fol. $64 \mathrm{r} ; 250$, fol. $18 \mathrm{v}$, entre molts altres.

${ }^{58} \mathrm{El} 1372$ el lloctinent de veguer de Rosselló es desplaça durant tres dies per anar "a la vayll de Banyuls per pendra I capellà encolpat de molts malefficis" (ACA, Reial Patrimoni, Mestre Racional, 1524, fol. 307v).

${ }^{59}$ ADPO 1B-146, fol. 175r; ACA, Reial Patrimoni, Mestre Racional 1525, fol. 76r.

${ }^{60} \mathrm{ACV}$, calaix 9, pergamí 547; AHCM, Fons del veguer, llibre 1323-1328, fol. $1 \mathrm{r}$.
} 
nos dictos officiales et comissarios (regios) si opus fuerit brachio secula$\mathrm{ri}^{\prime 61}$. A la segona meitat de la centúria, amb tensió i malfiança pels afanys de la monarquia de consolidar la preeminència a costa de l'Església, la invocació del bracchium seculare acostuma a ser un ocasional recurs per part de població no prou satisfeta per l'exercici jurisdiccional eclesiàstic ${ }^{62}$.

Tot i la nitidesa formal, la constant barreja de gent comporta confusions de jurisdicció, amb oficials reials acusats per haver-se apropat a persones i, encara més, béns vinculats a clergues ${ }^{63}$. La tensió sorgeix, però, per l'afany de l'Església en procedir sobre laics inculpats per eclesiàstics, sobretot per haver-s'hi obligat econòmicament. Alhora, la jurisdicció eclesiàstica prodiga àmplies citacions sobre molts seglars, a voltes per simples conflictes contractuals, cosa que provoca les queixes dels municipis i dels ordinaris, amb el suport reial ${ }^{64}$, en apreciar-hi un injustificat desig d'estendre la capacitat jurisdiccional eclesiàstica. Amb tot, les pretensions de l'Església insistiran puntualment en els diferents supòsits on es mescla la població: clergues agredits per laics ${ }^{65}$, concessió de tutories a eclesiàstics ${ }^{66}$ i, sobretot, les vinculacions creditícies, amb molts afectats, als que, en el cas concret de Barcelona, es refereix Pere III el 1372 en advertir al veguer i al batlle que "prohibirent omnes laycos ne comparent curiam officialibus dicti episcopi ratione censium"67.

Altres tipus de discrepàncies jurisdiccionals s'equiparen plenament a les tensions entorn a l'àmbit baronial, amb les discussions, tan usuals a inicis del segle XIV, per a escatir el contingut del domini cedit —mixt

\footnotetext{
${ }^{61} \mathrm{AHMV}$, llibre de Privilegis XIX, fol. 63r.

${ }^{62} \mathrm{ACA}$, Cancelleria, reg. 2002, fols. 4v-5r.

${ }^{63} \mathrm{El}$ sotsveguer de Besalú ha de comparèixer davant de l'oficial episcopal "a instància del capellà de Mata per ço com havien allegat que lo dit sotzveguer li havia treta de casa sua per força la serventa e penyores" (ACA, Reial Patrimoni, Mestre Racional 1556, fol. 92r). De fet, a Barcelona, l'acolliment que dues esclaves fugides trobaren al palau episcopal endega una discussió que "per XX annos dictam questio non esset decisa" (AHCBr, Fons municipal B-I, llibre 27 , fol. $95 \mathrm{v}$ )

${ }^{64} \mathrm{ACA}$, Cancelleria reg. 985, fol. 160r; AHCBr, C-V, caixa 1, plec "contra tonsuratos et personas eclesiasticas", sense numerar.

${ }^{65} \mathrm{El}$ govern municipal de Barcelona dictamina, explícitament, que "si negun lech naffrarà nall hom qui port corona, que.I veguer deja posar devant los prohoms e que $\cdot$ Is prohomens que 1 deien jutjar" (AHCBr, Fons municipal B-I, llibre 9, fol. 6v).

${ }^{66} \mathrm{~A}$ Vic, la tensió entre el municipi i l'episcopat per aquesta raó precisa, el 1338 , de la intervenció reial (ACV, pergamins calaix 37, Privilegis i estatuts IV, 73).

${ }^{67} \mathrm{ACHBr}, \mathrm{C}-\mathrm{V}$, caixa 1, plec "contra tonsuratos et personas eclesiasticas", sense numerar.
} 
imperi o mer i mixt imperi- i, al llarg de tot el segle, les infranquejabilitats jurisdiccionals, amb tibantors que inclouen les sortides en someten i amb divergències com les encallades a Tarragona entorn a les respectives capacitats de jurisdicció ${ }^{68}$. En altres casos els plantejaments eclesiàstics cerquen emparar-se en pretesos privilegis, com es fa el 1318 a Tarragona en voler eludir les limitacions generals de treure productes ${ }^{69}$. De manera més estesa, les tensions sorgiran amb l'afany reial d'imposar la capacitat exclusiva sobre les anomenades regalies, que es sumen al gruix de drets $\mathrm{i}$ rendes disputades en diferents diòcesis en forma de castlanies, lluïsmes i censos. Traspassat mitjan segle, aquestes discrepàncies sols s'inclinen favorablement vers el monarca a Elna, mentre que a Girona les respectives competències sobre la població ubicada en dominis episcopals perllonguen llargues discussions, amb punts emblemàtics com les negatives a participar en l'host reial ${ }^{70}$. Alhora, las divergències sobre la capacitat jurisdiccional territorial adopta uns trets propis entorn de les sagreres, que sobretot a Osona i sota Alfons el Benigne esdevenen disputades entre la corona i l'episcopat o entre aquest i els respectius dominis baronials ${ }^{71}$.

Més fàcils són les enteses en l'aplicació de sancions sobre la moralitat de la societat. Bé que l'Església n'expressarà la preocupació mitjançant les indagacions de les visites pastorals i estendrà ocasionals excomunions en casos d'incest o de matrimonis secrets, són els tribunals ordinaris els qui procedeixen respecte d'aquests aspectes, com també, de manera molt destacada, sobre el joc, la blasfèmia, el proxenetisme o l'adulteri. Fins i tot amb Joan I i encara més sota Martí I, el monarca invocarà la preocupació pels costums del clergat no sols per a intervenirhi $^{72}$ sinó fins i tot per a designar comissaris especials contra eclesiàstics, tot afermant el poder reial $\mathrm{i}$ els ingressos econòmics corresponents, segons

\footnotetext{
${ }^{68}$ AHT, II.2. Economia i Hisenda, procés 12, sense numerar.

${ }^{619} \mathrm{ACA}$, Cancelleria, reg. 244, fol. 6r.

${ }^{71}$ AHCG I.1.2.1, lligall 1, llibre 3, fols. 27v-28r.

${ }^{71}$ Flocel SABATÉ, El territori de la Catalumya medieval, Fundació Salvador Vives Casajuana, Barcelona, 1997, p. 86.

${ }^{72}$ El 1403, el rei Martí escriu al sotsveguer de Barcelona per tal que participi "havent vostre scrivà o notari" a costat de l'autoritat episcopal per a investigar "contra frare Miquel dez Puig, per paraules desonestes que dix no ha molt segons nos és donat entendre en la liçó que legia en lo Capitol de la Seu" (ACA, Cancelleria, reg. 2245, fol. 96r.; ed.: Faustino D. GaZULLA, Los reyes de Aragón y la Purísima Concepción de Maria Santísima. "Boletín de la Real Academia de las Letras de Barcelona", IV [Barcelona, 1907-1908], pp. 116-117).
} 
l'acord puntual amb l'episcopat, esdevingut ben regular a la diòcesi d'Elna, on es reiteren comissions mixtes, especialment sobre clergues concubinaris i sobre la pràctica de la usura ${ }^{73}$.

L'entesa entre ambdues jurisdiccions sempre és present en els àmbits on l'Església promou els tribunals: l'heretgia i la usura. La primera, amparada en una legislació heretada d'un segle prou sensible a la matèria com fou el XIII ${ }^{74}$, s'articula mitjançant l'"inquisitorem heretici pravitatis", designat pel Papa i auxiliat pels seus lloctinents o vicaris, amb percepció d'emoluments reials i amb el corresponent ajut de l'oficial ordinari en ser requerit $^{75}$. Les escasses discrepàncies, com les sorgides entorn a la capacitat d'incidir sobre la població jueva, són facilment acordades ${ }^{76}$. La concordança es reitera igualment en la persecució de la usura, definida com un pecat mortal ${ }^{77}$ i objecte de comissions tant papals com reials, sobretot des de Pere III $^{78}$. La gran extensió del crèdit, sota les diferents formes, permet dir que "nonnullus et maior pars singularium universitatis (...) involuti in crimine usurarum", justificant així que les comissions eclesiàstiques contra la usura esdevinguin simples excuses per a exigir remissions generals ${ }^{79}$ en uns moments en què la població s'està avesant a ser objecte, mitjançant fórmules similars, d'una "fiscalitat encoberta" per part de la monarquia. L'acord entre aquesta i l'Església pot, fins i tot, adreçar les percepcions a necessitats concretes del sobirà, com aprova Climent VII el 1393 en destinar la campanya contra la usura a subvencionar l'esquadra que Joan I prepara contra Sardenya i Còrsega ${ }^{80}$.

\footnotetext{
${ }^{73} \mathrm{ADPO}$ 1B-175, fol. 40r.

${ }^{74}$ Constitucions y altres Drets de Cathalunya, llibre I, tit X, caps. I-VI (Constitucions y altres Drets de Cathalunya, Departament de Justicia de la Generalitat de Catalunya, Barcelona. 1995, pp. 33-36)

${ }^{75}$ ADPO 1B-95, fol. 81v; 1B-100. fol. 33r; 1B-110, fol. 45r; 1B-121, fol. 24v: 1B-163, fol $12 \mathrm{r}$; $1 \mathrm{~B}-190$, fol. $48 \mathrm{r}$.

${ }^{76} \mathrm{ADPO}$ 1B-219, fol. $21 \mathrm{r}$.

${ }^{77}$ Tomàs Noguer I Musqueras; Josep Maria PONS I GurI, Constitucions sinodals de Girona de la primera compilació, "Recull d’Estudis d'Història Jurídica Catalana", Fundació Noguera, Barcelona, 1989, pàg. 201.

${ }^{78} \mathrm{AHCBr}, \mathrm{C}-\mathrm{V}$, caixa 1, plec solt, sense numerar; AHCTE, Clavari, llibre 13, fol. 159r.

${ }^{79} \mathrm{AHCV}$, Llibre del Consell 1393-1396, fol. 37r i 39r; AHCT, pergamins, caixa 13, 1396; $\mathrm{AHCBI}$, pergamí 54 , entre molts altres exemples.

${ }^{80} \mathrm{AHCBI}$. pergami 57; AHCT, pergamins, caixa 13, 1396.
} 
De fet, com recalca Pere III, les penalitzacions econòmiques pertanyen a la corona, raonament que limita l'Església a aplicar penes espirituals $\mathrm{i}$ a haver d'acceptar la creixent presència de la corona, fins i tot compartint la punició d'uns mateixos fets, com en determinades agressions a béns eclesiàstics ${ }^{81}$. L'entesa entre la intimidació civil i l'eclesial també es produeix en àmbits municipals, com a la Berga finisecular, on la venda de censals es reforça amb la protecció reial i eclesiàstica sota penes de presó i d'excomunió ${ }^{82}$.

\section{ESCRIVANIES I OFICIS REIALS VEDATS}

La separació jurisdiccional dels àmbits eclesiàstic i reial comporta la preocupació del monarca per evitar la presència de clergues detentant oficis reials. Es justifica, en primer lloc, per la impunitat que es derivaria de qualsevol irregularitat ${ }^{83}$, i en segon per l'increment de les malfiances davant dels integrants d'un altre col-lectiu de solidaritat, raó per la que els oficials regis tampoc han de "recipere pensiones, salaria aut quecumque benefficia a predictis ecclesiasticis aut secularibus personis cuiuscumque status seu condicionis existant", segons repeteixen els diferents monarques - sobretot Pere III el 1362 i el 1374 i Martí I el 1400- sense cloure pas la qüestióst.

Des del vessant eclesiàstic es limitava, a partir del concili lateranense de 1179, que els clergues participessin en tasques pròpies de juristes. $\mathrm{Al}$ segle XIII, però, arrela l'exclusió dels eclesiàstics dels oficis reials ${ }^{85}$ - "salvis cancellario et consiliario et elemosionario nostro et iudicibus qui

\footnotetext{
${ }^{81}$ AHMV, llibre de Privilegis, VIII, pergamí 155.

${ }^{82}$ Manuel RIu. La vila de Berga i els berguedans a la darreria del segle XIV. "Homenatge a la Memòria del Profesor Dr. Emilio Sáez", CSIC, Barcelona, 1989, p. 351.

83."Quod si delinquerent in aliquo, quod non possemus eos inde punire" (Cortes de Cataluña. "Cortes de los antiguos Reinos de Aragón y de Valencia y Principado de Cataluña". I. Real Academia de la Historia. Madrid, 1896, p. 173).

${ }^{84}$ ADPO 1B-346, fols. 148r-150r. 155r-v.

${ }^{85}$ Ferran VALLS I TABERNER, Els antics privilegis de Girona $i$ altres fonts documentals de la compliació consuetudinaria gironina de Tomàs Mieres, "Estudis Universitaris Catalans". XIII (Barcelona. 1928). p. 189.
} 
scrirentius" - sancionada per les corts de 1292, 1299 i $1300^{86}$, per bé que haurà de ser recalcada diverses vegades al llarg del segle XIV per cadascun dels monarques ${ }^{87}$. La mesura col-lideix, irremeiablement, amb el problema dels clergues conjugats i la seva identificació. Reiteradament es detecten diferents càrrecs que amagaven la condició de clergue conjugat, des del missatger del mostassaf de Lleida el 1350 a l'advocat fiscal de la vegueria del Bages el 1332, passant per nombrosos escrivans de les corts reials. En alguns casos l'afectat pretén retenir l'ofici tot renunciant a la condició clerical, com l'escrivà que a la cort reial perpinyanesa el 1316 es "treié la corona i no la tindrà d'aquí en avant" 88 . De fet, l'elevada presència en les escrivanies reials facilita acceptacions "de coniugatis autem clericis laycaliter" en el cas d'atorgar "sponsores laycos ydoneos et securos" i comprometre's a no al-legar fur eclesiàstic, tal com determina Alfons III el 1328 i especifica Pere III el 1341.

En general, el poder municipal insta a detectar i excloure els oficials amb origen de clergues conjugats ${ }^{84}$, per bé que en altres ocasions surt en la seva defensa, com a Puigcerdà el 1381 , quan fins i tot s'aconsegueix que el monarca, després de diverses dubitacions, accepti "que·ls clergues coniugats sien admesos en officials" ${ }^{\prime \prime}$. En realitat, malgrat les reiterades instàncies reials per a detectar els clergues conjugats ${ }^{91}$, la situació sempre es presta a les estratègies del poder. El 1328 Alfons III, en el conflicte amb la ciutat de Barcelona per la designació del cap de guaita, pot imposar el

\footnotetext{
${ }^{86}$ Cortes de Cataluña, "Cortes de los antiguos Reinos de Aragón y de Valencia y Principado de Cataluña", I, Real Academia de la Historia, Madrid, 1896, pàgs. 156; 172-173; Constitucions y Altres Drets de Cathalunya, Ilibre I, tit. LXVII, IV (Constitucions y Altres Drets de Cathalumya. Departament de Justicia de la Generalitat de Catalunya, Barcelona. 1995, pàg. 155).

${ }^{87}$ Pragmàticas y altres Drets de Cathalunya. Ilibre II tit. V 1-8 (Constitucions y Altres Drets de Cathalunya. Departament de Justícia de la Generalitat de Catalunya, Barcelona, 1995. "Pragmaticas". pp. 11-16): Cortes de Cataluña. "Cortes de los antiguos Reinos de Aragón y de Valencia y Principado de Cataluña". I, Real Academia de la Historia, Madrid, 1896, pàg. 172: $\mathrm{AHCBr} \mathrm{C}-\mathrm{V}$, caixa 1, plec "Contra tonsurats et personas eclesiasticas", sense numerar; ADPO 1B-146, fols. 45r-47r; 1B-206, fol. 87r; 1B-346, fols. 66v-71v; 1B-367, fols. 22r-31v: Johannes VINCKE, Documenta Selecta mutuas civitatis arago-cathalaunicae et ecclesiae relationes illustrantia. Biblioteca Balmes. Barcelona. 1936. p. 167.
}

${ }^{88} \mathrm{ADPO}$ 1B-95, fol. $41 \mathrm{v}$.

${ }^{89} \mathrm{AHCG}$ 1.1.2.1, lligall 2. llibre 2, fols. 26v-27r.

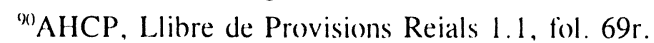

"ADPO 1B-95, fol. 4lv; Pragmàticas y altres Drets de Cathalumya, llibre II tit. V 2-4 (Constimcions y Altres Drets de Cathalumya. Departament de Justícia de la Generalitat de Catalunya. Barcelona. 1995. "Pragmàticas", pp. 11-14) 
propi candidat en acusar el detentor de l'ofici com a clericus coniugatus, mentre que a Vilagrassa, en el context de les diferències amb Tàrrega, disculpa la condició de clergue conjugat en el seu candidat a la batllia atès que "non obstante quod dictus Iacobus dicatur clericus coniugatus, haberens uxorem unicam et virginem dum tamen nec tonsuram nec vestes habeat clericales et layciter incedat" $"$ 2.

El monarca també vol extreure de l'àmbit eclesiàstic la possessió d'escrivanies, arran d'interpretar l'exclusiva competència reial en l'autorització de notaries i d'aprofitar l'expansió del notariat laic, afavorit, precisament, per les limitacions imposades per les Decretals papals a la participació dels clergues ordenats "in sacris" en la contractació de negocis temporals $i$ en l'administració de justícia ${ }^{93}$. L'arrelada tradició contrària argumentada tant per dominis nobiliaris com, sobretot, per una Església d'àmplia incidència popular en aquest sentit, mena, en el segle XIII, a puntuals acords i sentències arbitrals en diferents seus episcopals ${ }^{94} \mathrm{i}$ en determinades parròquies ${ }^{45}$. No estalvien, però, l'ofensiva reial de $1281^{96}$, aturada a les corts de $1283^{97} \mathrm{amb}$ el reconeixement de les autoritzacions efectuades pels respectius senyors sobre els dominis particulars, compaginat amb la capacitat reial sobre el conjunt de la Corona. El sobirà, doncs, no discutirà l'existència de notaries eclesiàstiques sobre els àmbits propis, però si que el titular delegui l'exercici a altres clergues, tal com detalla Jaume II el

\footnotetext{
"2ACA. Cancelleria, regs. 505. fol. 177v: 520, fol. 180r-v.

${ }^{93}$ Arcadi Garcia I SANZ, Precedents, origen i evolució dels col.legis notarials, "Actes del I Congrés d'Història del Notariat Català" (Barcelona, novembre de 1993), Josep M. SANS I Travé, coord., Barcelona, Fundació Noguera, 1994, pp. 168-171.

${ }^{94} \mathrm{ADPO}$ 1B-346, fol. 127v-132r.

${ }^{95} \mathrm{ACA}$, Cancelleria, reg. 340, fols. 22v.-23r.

${ }^{\circ}$ Rafael CONDE Y DELGADO DE MOLINA. La titularidad de las notarías parroquiales catalanas desde Pedro II (III) el Grande a Jaime II: del proyecto Besalui (128I) a la Pragmática de 1302, "Estudis sobre Historia de la Institució Notarial a Catalunya en honor de Raimon Noguera", Josep Maria SANS TRAvÉ, coord., Fundació Noguera, Barcelona, 1988, pp. 33-36.

${ }^{97}$ Cortes de Cataluña, "Cortes de los antiguos Reinos de Aragón y de Valencia y Principado de Cataluña". I. Real Academia de la Historia, Madrid. 1896, pàg. 144.
} 
$1302^{48}$, provisió recalcada tant per Alfons III com per Pere III que, en realitat, no serà respectada fora de la jurisdicció reial ${ }^{99}$.

Puntualment els oficials ordinaris, sovint amb el corresponent suport municipal, procedeixen contra clergues que practiquen la notaria, en general a la pròpia parròquia ${ }^{1(x)}$, alhora que s'allargassen discrepàncies d'interpretació dels acords previs ${ }^{101}$. Els greus conflictes, però, es generen quan l'autoritat eclesiàstica pretén avalar notaris en territoris de jurisdicció reial, com es viu sobretot a Tarragona i, encara més, a Girona. En la primera s'insereix en la disputa jurisdiccional ${ }^{102} \mathrm{i}$ amb intermitències es perllonga fins que l'arquebisbe assoleix el domini sobre el Camp de Tarragona el 1391. A Girona, les pretensions episcopals, tolerades vitalíciament per Jaume I en la persona del bisbe Pere de Castellnou, mort el 1279, seran combatudes pels successius monarques el 1320, 1330 i 1336. El 1365, però, esclata el greu conflicte, quan el bisbe pretén efectuar nomenaments i el monarca ho vol impedir, convertit en una topada violenta, amb les hosts locals contra uns familiars episcopals detinguts, posant en joc totes les armes eclesiàstiques i reials ${ }^{103}$. Les trames de Girona i de Tarragona s'enllacen, amb el suport ofert pel metropolità al gironí i la reacció del monarca en contra seva el $1366^{104}$.

El rei recalcarà per a tot arreu, el 1373, que ningú "no gos fermar cartes públiques ne testaments ne altres qualsevol contractes en poder de notaris o scrivans de prelats, de abbats ne d'esglésies ho rectons d'aquelles

\footnotetext{
${ }^{98} \mathrm{AHCBr}, \mathrm{C}-\mathrm{V}$, caixa 1 , plec "contra tonsurats et personas eclesiasticas", sense numerar; Pragmàticas y altres Drets de Cathalumya, llibre II tit. V.1 (Constitucions y Altres Drets de Cathalunya, Departament de Justícia de la Generalitat de Catalunya, Barcelona, 1995, "Pragmàticas", p. 11).

99" La provisió feita pel senyor rey que cartes públiques sien escrites per persones layches o que Is clerges que $\mathrm{i}$ auctoritat an de fer aqueles façen aqueles personalment o ffaçen servir l'offici de la notaria per persones layches, no's té ne s"observa sinó en los lochs del senyor Rey, e no en tots aquels" (ACA, Cancelleria, "Papeles por incorporar", Cervera, sense numerar).

${ }^{100}$ AHCTE, Provisions, 3, fol. 13v.

${ }^{101}$ Maria Teresa FERRER I MALLOL, L'expansió d'una regalia al començament del segle XIV: el notariat reial, "Estudis Històrics i Documents dels Arxius de Protocols", XIII (Barcelona, 1995). pp. 60-63.

${ }^{102}$ AHT, Secció II.2. Economia i Hisenda, plet 12, fol. 58v.

${ }^{10: 3} \mathrm{Josep}$ Maria PONS GURI, El conflicte de la notaria de Girona, "Anales del Instituto de Estudios Gerundense", XXV/I (Girona. 1979-1980), pp. 167-236; "Recull d’Estudis d'Història Jurídica Catalana", I, Fundació Noguera, Barcelona, 1989. pp. 33-93).

${ }^{104} \mathrm{ACA}$, Cancelleria, reg. 985, fol. 159r-v.
} 
ho altres qualsevol persones ecclesiàstiques"105. La mesura, que pretén consolidar el poder del sobirà, es remet a la manca de compliment de les garanties constitucionals en els notaris no reials, per bé que col-lisiona amb un món rural avesat a les pràctiques notarials de rectors i vicaris, moltes vegades imprescindibles per a no caure en intestacions. Per això el 1374 el monarca acceptarà els usos consuetudinaris, tant en els àmbits rurals gironins com entre població reial atreta per capitalitats de jurisdicció eclesiàstica, del caire de Guissona o Sanahuja, i el testament parroquial perviurà en els segles posteriors $^{106}$.

Tanmateix, les exigències de respectar la infeudació de les notaries de la ciutat, batllia i vegueria de Girona, contra les renovades pretensions bisbals, propicien fortes topades a partir de 1377 entre la jurisdicció reial i l'episcopal ${ }^{1177}$. La contundència emprada incita a indagar en les armes esgrimides per l'Església.

\section{DISCURS I ARMES DE L'ESGLÉSIA}

L'Església secular sol proclamar, davant de les discrepàncies, una voluntat de servei i de concòrdia, convençuda que "lex boni hominis est lutes execrari et maxime religiosi proprium est lutes aborrere"108. Justifica la seva presència i actuació per raó del servei prestat a través de les pregàries i de l'atenció als pobres, disposició que l'eximeix d'altres contribucions a la col-lectivitat social, malgrat la disparitat dels qui no ho entenen ${ }^{109}$. Aquest discurs es compatibilitza amb l'aferrissada defensa de tots els indicis de jurisdicció i capacitats d'intervenció. La retòrica reiteradament encerta imatges veterotestamentàries que assimilen els conflictes de l'Església baixmedieval contra els poders municipals i les autoritats reials amb el poble escollit sotjat per babilònics o pel faraó egipci.

\footnotetext{
${ }^{105}$ AHCT, Ilibre de la Cort del Batlle, 1, fol. 15r.

${ }^{106} \mathrm{~J}$ osep Maria Pons GURI, El testament parroquial gironí en el segle XIV, "Recull d'Estudis d'Història Jurídica Catalana", I, Fundació Noguera, Barcelona, 1989, pp. 25-27.

${ }^{107}$ Maria Teresa FERRER, Notariat laic contra notarial eclesiàstic. Un episodi de la pugna entre ambdós a Girona (1347-1380), "Estudios Históricos y Documentos de los Archivos de Protocolos", V (Barcelona, 1977), pp. 21-31.

${ }^{108}$ AHCTE, Paeria i Vegueria II, 24, fol. 8r. $11 \mathrm{v}$

${ }^{109} \mathrm{AHCV}$, Administració de Justícia. Cort del batlle, processos 1391, sentència plet, fol.
} 
Formalment, l'Església basa el seu ordenament intern en els canons aprovats pel concili de la província eclesiàstica tarraconense, les Constitutiones sacri concilii Tarrachone. És el corpus doctrinal permanentment citat des de l'arrencada propiciada pel concili de Lleida de 1229, compilat el $1330^{110}$ i que encara pot ser concretat pels diferents sínodes diocesans amb les respectives constitutiones sinodales ${ }^{11}$. Els canons recullen les disposicions sobre la moralitat dels clergues, incloses les advertències a "omnis clerici coniugati vel alii in minoribus ordinibus tonsurati", amb limitacions a l'absentisme i a l'accés al crèdit o a les armes. Igualment, s'hi precisa la protecció de les persones i béns de l'Església contra "omnes invasores et raptores et depredatores rerum eclesiasticarum et locum religiosorum" ${ }^{\prime \prime 2}$. D'aquesta manera, les Constitucions Tarraconenses passen a emparar totes les situacions i supòsits en què intervé l'Església. En els diferents conflictes entorn a la jurisdicció territorial o personal, la institució eclesiàstica gaudeix així d'una arma particular: amenaçar amb "les penes contengudes en les Constitucions del Sacre Conseyl de Terragona fetes e promulgades contra los usurpadors -o contra los invasidors e occupadors- dels béns e drets eclesiàstichs" 113

El servei diví propi del clergue permet sumar-hi, alhora, l'agreujant "ratione sacrilegii", com en les primeres dècades del segle aplica el bisbe de Tortosa i com el 1334 pretén generalitzar l'homòleg gironí "can s'esdeven que algun lec fer o nafre alcun muleyrat haven corona"1/4, pretensions que amaguen el deler per les penes econòmiques inherents i que, per això mateix, el monarca podrà fer descartar en limitar les penalitzacions eclesiàstiques als àmbits espirituals.

Els succesius concilis provincials permeten legislar sobre els temes candents, augmentant així la capacitat d'incisió de les Constitucions de Tarragona: coincidint amb la pugna per les notaries, el 1364, el $1367 \mathrm{i}$ el

\footnotetext{
${ }^{110}$ Josep Maria PONS GURI, Constitucions conciliars tarraconenses (1229-1330), "Recull d'Estudis d'Història Jurídica Catalana", II, Barcelona, Fundació Noguera, 1989, pp. 223-287.

I'Tomàs Noguer I Musqueres; Josep Maria PONS I GURI, Constitucions sinodals de Girona de la primera compilació. "Recull d'Estudis d'Història Jurídica Catalana", II, Barcelona, Fundació Noguera, 1989, pp. 81-222.

112Josep Maria PONS GURI, Constitucions conciliars tarraconenses (1229-1330), "Recull d'Estudis d'Història Jurídica Catalana", II, Barcelona, Fundació Noguera, 1989, pp. 321, 328, 354-355, 359-360, 369, 370, 379.

${ }^{113}$ ACA Monacals Hisenda 896, fols. 99v, 221v, entre molts altres exemples.

${ }^{114}$ AHCG I.1.2.1, lligall 2, llibre 2, fol. 26r.
} 
1369 els canons conciliars recolzen les escrivanies eclesiàstiques i arriben a decretar l'exclusió de les reials en les zones pertanyents a l'Església.

La pena aplicable als incompliments de les Constitucions és l'exclusió de la comunitat cristiana, és a dir, l'excomunió. Tots els oficials jurisdiccionals civils s'arrisquen a caure-hi en detenir algú que alegui ser clergue, inclosos els conjugats, o en intervenir dins de qualsevol indret considerat de jurisdicció eclesiàstica. La mateixa penalització pot estendre's, sota la fórmula de l'entredit, a poblacions senceres, ja sigui pel suport ofert als oficials ordinaris o per les discrepàncies en els diferents aspectes en discussió. Es multiplica, doncs, un elevadíssim nombre de veguers i batlles sota excomunió, alhora que la interdicció de viles i ciutats es reitera: el 1333 les discrepàncies fiscals entorn de les talles culminen amb l'entredit de Vic, situació repetida el 1356 per les tensions entorn a la cessió a Bernat de Cabrera. Conflictes jurisdiccionals poden menar a l'entredit de demarcacions senceres, com el comtat d'Empúries el 1355 arran de les diferències entre el comte emporità i el bisbe de Girona per Foixà. Com tants altres indrets, Barcelona és entredita el 1341 arran d'haver detingut el veguer un clergue i Lleida n'és el 1350 perquè el missatger del mostassaf continua arrestat malgrat identificar-se com a clergue conjugat. Fins i tot el cas del castellà detingut a Perpinyà per assassinar la seva esposa que a la presó simula ser un clergue desemboca en l'excomunió del batlle i l'entredit de tota la vila. Precisament, el 1368 l'exigència de l'ajuda de la carn als clergues mena Perpinyà a la interdicció, endegant un conflicte que s'enrarirà i s'allargassarà vuit anys. Manresa viu entredita de 1340 a 1345 per la indisposició episcopal a què la cèquia reial de la ciutat travessi indrets sota jurisdicció del bisbe de $V i^{115}$. A la interdicció s'hi arriba molt sovint per espurnes de poc gruix: el 1384 hi cau la vila d'Elna formalment pel deute de set sous que el consolat es nega a pagar, alhora que un lloc petit com l'Albiol el 1313 ja havia estat entredit amb el seu batlle per les discrepàncies arran de la penyora de dues cabres.

La banalització d'aquestes penes s'emmarca en una dinàmica generalitzada a Occident ${ }^{116}$. Les excomunions a particulars s'apliquen, ja

\footnotetext{
115 Joaquim SARRET I ARBós, La cèquia de Manresa, Estampa Catòlica de Domingo Vives, Manresa, 1906 (facsímil, 1987), pp. 36-40.

${ }^{116}$ Norah B. Ramos, La Iglesia a través de las Cortes castellanas. Uso y abuso de la excomunión (ss. XIII-XIV), "Cuadernos de Historia de España", LXIX (Buenos Aires, 1987), pp. $102-107$.
} 
a la primera meitat del segle XIV, per crèdits no tornats, contractes desatesos o penes de terces incomplertes, en un abundant nombre que les dificultats de la segona meitat de la centúria acreixerà ${ }^{117}$. En funció del deute, fins i tot es graduarà l'excomunió temporalment, com es reitera en el darrer terç de segle amb les excomunions d'un any de durada ${ }^{118}$. Assumida com a eina coercitiva, també serà aplicada als laics que no compareixin als requeriments de les corts eclesiàstiques, responent així a les crítiques de la jurisdicció ordinària contra tantes citacions ${ }^{119}$.

En tots els casos, es pot apel-lar al tribunal metropolità de Tarragona i a la cort papal, vies usuals que allargassen els processos amb notòria despesa per als eraris de les entitats apel-lants ${ }^{120}$. És mitjançant la intervenció del papa que el 1307 la ciutat de Barcelona es lliura de la interdicció imposada al 1304 arran de la negativa de dos ciutadans a pagar el lluïsme per unes cases de propietat eclesiàstica ${ }^{121}$.

Al mateix temps, el lloc ocupat per l'Església, com a braç estamental, a les Corts generals és reiteradament utilitzat per a plantejar greuges respecte dels diferents conflictes ${ }^{122}$. La protecció atorgada per les Constitucions de Catalunya, en incorporar les inicials Constitucions de Pau i Treva ${ }^{123}$, no és gaire reivindicada per l'Església, en témer-hi una via d'ingerència del monarca que està, precisament, fonamentant la pròpia autoritat com a garant exclussiu d'aquestes Constitucions. De fet, la jerarquia eclesiàstica també empra la seva influència en l'accés directe al sobirà, que en cada decisió haurà d'optar entre les diferents pressions de què és objecte.

Alhora, l'ascendent sobre les consciències, en una mesura o altre, és un dels trets característics d'una autoritat espiritual. La predicació és assumida com una eina per a escampar els propis arguments, com fa el bisbe

\footnotetext{
${ }^{117} \mathrm{AHCP}$, registre de la cúria eclesiàstica de Puigcerdà, 1, fol. 5v; AHCT, pergamins, caixa 12, 1395, entre molts altres.

${ }^{118}$ AMSJA, Carpeta cúria secular. Processos s. XIII-XIV, plec "Fragments de processos del segle XIV", sense numerar.

${ }^{119} \mathrm{ADPO}$ 1B-146, fol. 171r-v:

${ }^{120}$ AHMV, Llibre de Privilegis XX, pergamí 341 ; Llibre de Privilegis XXIX, pergamí 409; ADG, calaix 7 , pergamins 88-89.

${ }^{121}$ Francesch CARRERAS Y CANDI, Notes sobre los origens de la enfiteusis en lo territori de Barcelona, "Revista Jurídica de Catalunya", XVI (Barcelona, 1910), pp. 75-85.

${ }^{122}$ ACA, Cancelleria, lligall de greuges i processos de greuges (1333-1431), sense numerar.

${ }^{123}$ Cortes de Cataluña, "Cortes de los antiguos Reinos de Aragón y de Valencia y Principado de Cataluña". I. Real Academia de la Historia, Madrid, 1896, p. 96.
} 
de Girona quan, arran del conflicte de les notaries, el 1366 "per plateas et vicos et per tronas predicari publice fecisse"124. És una actitud que l'autoritat civil retreu com a ús parcial i inapropiat de la trona per a tractar de manipular la població en favor propi, a voltes amb poca dissimulació, segons s'explica en el conflicte jurisdiccional viscut a Tarragona ${ }^{125}$.

A la consciència del poble també s'hi accedeix a partir de les creences i llegendes, constitutives de la comuna imatge de la religió. Precisament, les centúries precedents s'havien omplert de narracions populars amb la figura d'una divinitat que s'ofenia i prenia venjança sobre qualsevol no sols que robés sinó que s'apropés excessivament als béns de l'Església ${ }^{126}$.

\section{EL CONFLICTE DE LES TEMPORALITATS}

El monarca ha de cercar, en el seu àmbit, armes equiparables a les emprades pel poder eclesial. Mesures com el desterrament del bisbe de Vic, arran dels conflictes de 1356, no poden ser més que excepcionals. Si els bisbes poden argumentar la màxima capacitat en matèria espiritual, el sobirà pot contraposar la suma potestas sobre les jurisdiccions temporals a tenor del discurs d'enlairament del poder reial coetàniament empès pels assessors romanistes, que ja provoca la topada amb l'Església entorn a les Constitucions de Pau i Treva ${ }^{127}$. En coherència, la corona rèial respon als conflictes de 1366 a Girona i de 1368 a Perpinyà decretant "pendre la temporalitat del Bisbe".

\footnotetext{
${ }^{124}$ ACA. Cancelleria, reg. 1787, fol. 123r (Josep Maria PONS GURI, El conflicte de la notaria. "Anales del Instituto de Estudios Gerundenses" XXV-I [Girona, 1979-1980], p. 191: "Recull d'estudis d’Història jurídica Catalana", I, Fundació Noguera, Barcelona, 1989. p. 56).

125"Cum dominus Rex possideat homines Civitate Terrachone qui sunt propii et solidi, ipsius vicarius arquiepiscopi convocavit partem populi dicte Civitatis sub colore quod volebat eis predicare verbum Dei in sede eiusdem Civitatis cum simbalo majori, et cum fuerunt ibi convocati, fecit claudi ianuas dicte sedis et ibidem ipsos inflamavit contra iura regia et commovendo quantum in ipso vicario fuit contra bonum publicum et utilitatem (...) ipsius Civitatis" (AHT, Secció II-2, Economia i Hisenda, núm. 12, fol. 19v).

${ }^{126}$ Pierre André SIGAL, Un aspect du culte des saints: le chatiment divin aux XI" et XII" siècles d'après la littérature hagiographique du Midi de la France, "Cahiers de Fanjeaux", 11 (Toulouse, 1976), pp. 42-45.

${ }^{127}$ Flocel SABATÉ, Discurs i estratègies del poder reial a Catalunya al segle XIV, "Anuario de Estudios Medievales", 25 (Barcelona, 1995), p. 629.
} 
A la capacitat de segrestar els dominis temporals de l'Església pretesa pel monarca, els prelats contraposen la invulnerabilitat dels béns eclesiàstics segons les Constitucions tarraconenses i, sobretot, la infranquejabilitat jurisdiccional sobre els dominis baronals reconeguda per les Constitucions de Catalunya de 1283 i 1228. De fet, l'arrelada vivència en aquest sentit comporta, fins i tot, la dificultat de comprensió dels propis oficials reials, com el veguer de Girona, a qui l'infant Joan ha d'explicar, el 1366, que la possessió de plena jurisdicció per part del bisbe sobre els seus dominis no vol dir que aquests indrets "no sien dins la vagueria de Girona" ni que el sobirà no hi gaudeixi d'una preeminència suprema. L'infant arriba a qüestionar les constitucions aprovades sota pressió dels estaments: "rebujam de obeyr aquella" diu respecte de les garanties jurisdiccionals aprovades en corts, atès que la constitució "fou obtenguda en les Corts quan los prellats no volien consentir a l'ajuda si allò no.ls fos acordat" ${ }^{128}$.

Amb greus discrepàncies a Elna i a Urgell, els problemes d'escrivanies, bàndols $\mathrm{i}$ interpretació de la capacitat jurisdiccional enrareixen la tibantor, sobretot, a Girona i a Vic, i es sumen a les fortes tensions de Tarragona, on el monarca invoca les Constitucions de Pau i Treva per a procedir "contra clericos etiam in sacris constitutos et contra prelatos". També les invoca arreu per a justificar que els oficials ordinaris entrin, "processus soni emisi", dins dels dominis baronials tant en mans laiques com eclesiàstiques, alhora que, com a garant de la justícia, pretén una capacitat de revisió suprema. El conjunt, repetit en dominis monàstics com en l'emblemàtic enfrontament amb Sant Benet de Bages, indisposa tota la jerarquia eclesiàstica, que és recolzada el febrer de $1372 \mathrm{amb}$ una decretal de Gregori XI ${ }^{129}$.

La tensió s'apaivaga amb la concòrdia establerta entre el cardenal Bertran de Cognac, bisbe de Comenges, en qualitat de llegat papal, i la reina Elionor de Sicília, signada el juny del mateix any ${ }^{130}$. En ella el monarca es compromet a respectar tant els clergues, que escapen a la seva com-

\footnotetext{
${ }^{128}$ ACA. Cancelleria, regs. 1707, fol. 177v; 1787, fol. 132v (ed.: Josep Maria Pons GURI, El conflicte de la notaria de Girona, "Anales del Instituto de Estudios Gerundense", XXV/I (Girona, 1979-1980), pp. 207-208: "Recull d'estudis d'Història jurídica Catalana", I, Fundació Noguera, Barcelona, 1989, pp. 69-70).

${ }^{129}$ Johannes VINCKE, Documenta selecta mutuas civitatis arago-cathalaunicae et ecclesiae relationes illustrantia, Biblioteca Balmes, Barcelona, 1936, pp. 481-484.

${ }^{1.30} \mathrm{ACA}$, Cancelleria, Memorial 45, fol. 66v. Agraeixo a l'arxiver Jaume Riera el generós ajut prestat en el seguiment de les pistes documentals a l'Arxiu de l'antiga Cancelleria Reial.
} 
petència en tots els supòsits, com els béns i dominis de l'Església, que no seran danyats amb l'excusa de les persecucions so metent, de la mateixa manera que no seran bandejats del país eclesiàstics i que els conflictes de jurisdicció seran sotmesos a arbitratges ${ }^{131}$. El fort ressò de l'acord ${ }^{132}$, convertit en punt de referència per al posteriors tractes entre la monarquia i l'Església, no pot impedir que les tensions es reprenguin. La reiterada queixa eclesiàstica aconsegueix l'explícita aprovació de la concòrdia pel rei Martí el $1409^{133}$, l'exhortació al seu compliment per Ferran I el $1413^{134}$ i l'aprovació per Alfons IV dels capítols de Sant Cugat el $1419^{135}$. De fet, la controvèrsia "super facto temporalitatum eclesiasticorum", lluny de tancarse, esdevé un dels temes candents de la primera meitat del segle $\mathrm{XV}^{136}$, aconseguint-se l'acceptació, per part de l'Església, que existeix "lo cas on, servades les coses desús dites, se hage a fer ocupació de temporalitats".

A Elna, on la problemàtica s'ha complicat entorn a les respectives capacitats jurisdiccionals i a la pretensió episcopal de percebre l'estacatge a la costa, es pot arribar a un acord a partir de la discussió dels capítols de $1424^{1.37}$. El monarca acceptarà "de non ocupandis temporalitatibus", però els estils de la cort del veguer rossellonès aconseguiran incloure que "totes persones eclesiàstiques exemptes del for del bisbe són civilment de for del senyor Rey e de son veguer", que "lo bisbe ni sos officials no han conexensa de censos ni rendes amortitzades encara que siguen de luyció" i, fins i tot, que "lo senyor bisbe ni sos officials no poden possar entredit, e si.n posen és procehit per lo veguer contra ells per capció de juridicció e rendes de la mensa episcopal"138.

\footnotetext{
${ }^{131}$ Constitucions de Catalumya. Incunable de 1495, Departament de Justícia de la Generalitat de Catalunya. Barcelona. 1988, pp. 568-570.

${ }^{132} \mathrm{AHCBr} \mathrm{C}-\mathrm{V}$, caixa 1, plec solt, sense numerar: ADPO IB-146, fol. 152r.

$1:$ ACA. Cancelleria, reg. 2214, fols. 145r-148v.

${ }^{1.34} \mathrm{ADPO}$ 1B-146. fol. 152v

${ }^{135}$ Constitucions de Catalumia. Incunable de 1495. Departament de Justicia de la Generalitat de Catalunya. Barcelona, 1988. pp. 577-585.

$1: 36$ ACA, Cancelleria, Memorial 22 bis, sense numerar.

${ }^{1: 7} \mathrm{ADPO} 1 \mathrm{~B}-346$, fols. $150 \mathrm{v}-152 \mathrm{v}$.

${ }^{138} \mathrm{ADPO} 1 \mathrm{~B}-346$, fol. $177 \mathrm{r}$.
} 


\section{RELACIONS A LA CÚPULA DEL PODER}

Durant el primer quart de segle, el rei tem el pes adoptat pels concilis provincials i cerca la manera d'incidir-hi, d'evitar abusos amb l'excomunió i de retallar la puixança episcopal fins i tot fragmentant les diòcesis de Girona i de Vic ${ }^{139}$, alhora que discuteix amb els prelats tant en exigir subsidis com en les diverses discrepàncies sobre la capacitat jurisdiccional territorial. Tot això no enterboleix, però, una entesa comuna enfront, sobretot, del poder nobiliari, com es palesa amb claretat en els problemes del bisbe de Vic amb els Montcada ${ }^{1+1}$. En aquesta situació el monarca no té recança a situar "la terra de l'Esglea d'Urgel en son guiatge" ${ }^{1+1}$, en una línia continuada sota Alfons III i els inicis de Pere III, quan els clergues de la ciutat de $V$ ic reben un guiatge reial de llargues conseqüències ${ }^{1+2}$.

Traspassat mitjan segle, les discrepàncies esdevenen molt tenses en afegir, als diversos conflictes jurisdiccionals, una suma de divergències als diferents bisbats que tenen, com a denominador comú, les pretensions d'afermament del poder reial a través d'escrivanies, regalies i temporalitats. Pere III aplica una actitud força autocràtica sobre l'Església, en part afavorit per l'existència, des de 1378, d'un cisme en el que no es decanta per cap banda per a poder així tant retenir les rendes com aplicar els propis designis en l'Església catalana, i en part per la consolidació d'uns àmbits propis d'incidència, on hi té molt a veure la línia directa establerta amb el papat per a demanar prebendes pels eclesiàstics, cosa que li garanteix un ascendent sobre molts clergues. La contundència del monarca - per exemple en maltractar físicament al col-lector episcopal que l'ha excomunicat el 1370forma part, en realitat, de l'afany per aprofitar totes les escletxes d'intervencionisme, fins i tot amb les armes, com s'esdevé el 1386 al fer actuar amb les hosts el portantveus de governador a Constantí a favor del cambrer de

\footnotetext{
${ }^{139}$ Johannes VINCKE, Estado e Iglesia en la Historia de la Corona de Aragón en los siglos XII, XIII y XIV, "VII Congreso de Historia de la Corona de Aragón (Barcelona, 1962)", I, Barcelona, 1962, p. 279: Odilo ENGELS. Los reyes Jaime II y Alfons IV de Aragón y los concilios provinciales de Tarragona, "ViII Congreso de Historia de la Corona de Aragón (Valencia. 1967). II, Valencia. 1970. pp. 258-261.

140 ACV. calaix 7. 526: calaix 9. pergamins del bisbe Ponç de Vilaró, 1301: AEV. pergamins llibre IV. 30 .

${ }^{1+1}$ ACA. Cancelleria, "Papeles por incorporar". Cervera, sense numerar.

14-AHMV, Llibre de Privilegis IV, pergamí 11; V, pergamí 83.
} 
Tarragona ${ }^{143}$. La major feblesa d'un rei Joan escàs de recursos imposa una entesa en certa manera continuada pel rei Martí, que deixa escolar les tensions entorn a les temporalitats alhora que assoleix vies de penetració mitjançant les diferents comissions especials sobre matèries com la usura $\mathrm{i}$ l'heretgia i sobre àmbits com els mateixos clergues.

En realitat, es ressegueix una línia directe entre els prelats i el monarca, el qual ha d'optar entre les diverses pressions procedents dels diferents poders. En aquest context, poden produir-se importants transtorns polítics mentre que el corresponent prelat $\mathrm{i}$ el rei mantenen un bon tracte personal, com en el cas de l'arquebisbe Pere de Clasquerí, amb qui Pere III confia com a canceller quan ja estan esclatant seriosos problemes a Tarragona. El canvi en la relació entre aquests personatges evidencia com el curs polític pot capgirar aparents certeses, tal com també exemplifica Ènyec de Vallterra, que, essent bisbe de Girona, apareix com a cabdal enemic de Pere III en excitar el conflicte de les notaries el 1365 i és, per això, remogut a la diòcesi d'Albarrasí-Sogorb, però després s'entendrà amb el mateix monarca, el representarà davant la cort papal a Avinyó i gràcies a ell serà arquebisbe de Tarragona. De fet, malgrat totes les tensions, s'estableix una proximitat entre els bisbes i el monarca, usual també en els regnes veïns ${ }^{14}$, i coherent amb la preocupació del rei per a incidir en les designacions episcopals.

Les concessions del sobirà als bisbes poden perjudicar l'eficàcia i la imatge de la jurisdicció ordinària. En ocasions per imposar-li modificacions $i$ en altres per limitar-li capacitats d'actuació, tal com succeeix a Vic, amb uns clergues reiteradament afavorits pel monarca $-1315,1320,1339$, 1350-, amb beneficis que els emparen com a deutors, segons es diu el 1317. o que incrementen la impunitat dels clergues tonsurats, cosa que motiva la queixa del govern municipal el $1337^{145}$. Per raó de la concordança establerta entre els prelats i l'entorn reial, l'oficial regi pot ser objecte

\footnotetext{
${ }^{14:} \mathrm{AHPB}$, Notari Joan Eiximenis, lligall 15, "protestacionum et sentencialitet liber" (13771389). sense numerar.

${ }^{1+1}$ José Manuel NiETO. Las realidades cotidianas de las relaciones Monarquia-Episcopado en Castilla. Siglos XIII-XIV, "État et Église dans la genèse de I'Etat moderne". J. P. Genet et B. Vicent, éds.. Casa de Velázquez. Madrid. 1986. p. 334.

${ }^{145} \mathrm{ACV}$. calaix 37, Privilegis i Estatus, II, pergami 30: Privilegis i Estatuts III. pergamí 62: calaix 37, privilegis i estatuts III, pergamí 51: AHMV. Llibre de Privilegis V, pergamí 83 Llibre de Privilegis IV, pergami 11 .
} 
d'amonestaciól ${ }^{146}$ i de correcció, com el sotsveguer de Besalú al que el 1366 se li diu que "restituatis et ad pristinum statum reducatis" les penyores de temporalitats del bisbe de Girona que ha extret per ordre del mateix monarca. Els canvis obeeixen a estratègies del rei - pressionar abans de l'acord-o, majorment, a alteracions en els equilibris de forces. En tots els casos, són els oficials els més exposats i els que, arribat el cas, poden haver de córrer amb els inconvenients de ser excomunicats ${ }^{147}$. I també és la imatge de la justícia l'afectada, en la convicció que els tractes econòmics entorn al sobirà poden comportar remissions, permisos i canvis de fur que, en definitiva, dificulten l'exercici judicial. Tot plegat imposa constatar el parer popular.

\section{VERS L'ANTICLERICALISME POPULAR}

L'Església, a través de les Constitucions Tarraconenses, legisla contra clergues en concubinatge, tafurers i altres comportaments impropis tot decretant "de vita et honestate clericorum", a la vegada que tramet visites pastorals que indaguen en la moralitat de clergues i laics. Alhora, però, la mateixa jerarquia, amb la facilitat de concedir llicències, contribueix a un creixent absentisme que, de manera ben accentuada a la segona meitat del segle XIV, va convertint les rectories parroquials en font d'ingressos per a un clergat rendista que delega $\mathrm{i}$ sotsdelega les tasques pastorals a uns capellans ben poc preparats intel-lectualment, amb una imatge més propera a la dels expenedors de sacraments que no pas als possessors de preocupacions morals ${ }^{148}$.

Les rendes de les parròquies assoleixen, en aquest context, un important protagonisme, tant per ser arrendades, transaccionades o discutides

\footnotetext{
146" Nós vullam que vós e los altres officials nostres mantengats e defenats nostra jurisdicció, e per açò e per retre justícia vos hi possam, però no volem i no manam que tolgats ni usurpets res a la Yglésia" (ADPO 1B-346, fols. 50v-52v).

${ }^{1+7}$ Es prou significatiu que el batlle de Perpinyà, excomunicat per no cedir a l'autoritat episcopal el castellà acusat d'uxoricidi que simulava corona, ha de córrer amb les despeses de la pròpia apel.lació (ADPO 1B-346, fol. 170r).

1+8"La papauté en agissant ainsi désorganitsait la vie de l'Eglise dans ses cellulles initiales", enmig d'una situació en la que "l'énorme majorité du clergé paroissial à la fin du XIII" siècle et au début du XIVe nous paraît plutôt médiocre, négligeant ou même incapable de dirigir et d'instruire ses ouailles" (Guy DEVAILLY. L'encadrement paroissial: rigueur et insufissance. "Cahiers de Fanjeaux", 11 [Toulouse, 1976], pp. 411: 412-413).
} 
entre el rector i el vicari, com per entrar en col-lisió amb els mateixos parroquians, ja sigui arran de conflictes per percepcions com el delme o, de manera ben estesa, per les exigències pels actes litúrgics, sobretot batejos, casaments $\mathrm{i}$, molt destacadament, funerals ${ }^{149}$. La mateixa actitud de la jerarquia, que amb facilitat dispensa d'incest o d'usura mitjançant el degut pagament, unit a totes les tensions públiques, accentua la visió popular negativa respecte del clergat.

El clerge és caracteritzat, en primer lloc, pel seu afany pel diner, tal com recull tota la literatura baixmedieval ${ }^{150}$. I, tot seguit, per la seva desordenada passió pel sexe femení, cosa que esdevé un dels llocs comuns de la cultura popular ${ }^{151}$, tot entretenint les converses i rondalles entorn de si els fills de capellans s'infanten amb major dolor, si els clergues fornicadors de dones casades requereixen o no el perdó dels marits abans del de Déu o, també, de què passarà al més enllà amb les concubines d'eclesiàstics ${ }^{152}$. La malfiança que mereixen els clergues els fa assimilar als jueus: mentre el bisbe d'Angers reflexiona que "les prêtres sont regardés par les laïcs comme plus vils et plus méprisables que les juifs"153, a Girona els jurats apleguen clergues $\mathrm{i}$ jueus com a responsables del deteriorament de la

${ }^{1+19}$ AHCM, pergamí 354; AHMV, llibre de Privilegis XIX, fols 100r-101r; APSMM, pergamí 14.001 ; BC, pergami $5253,2-1-2$

${ }^{150}$ Valguin els exemples de loccità Pèire Cardenal al segle XIII ("Tartarassa ni voutor/ no sent tan leu carn puden / quom clerc e prezicador / senton ont es lo manen / Mantenen son sei privat. I e quant malautia-I bat. I fan li far donassio / tal que.I paren no.i an pro" [Peire CARDEnal. Tartassa mi voutor. "Poesia trobadoresca". Edicions 62 i "la Caixa". Barcelona. 1982. pp. 280-281|) i. al segle XV. dels castellans López de Ayala ("A quien tiene oro e plata. çinco obispados val; / aunque sea letrado, si aquesto le fal, / non le dan beneficio por la su tal decretal" (Pero LÓPEZ DE AYAla, Libro rimado del Palaçio. I. Editorial Alhambra. Madrid. 1978, p. 89]) i la Crònica d'Enric IV de Castella, en parlar de "las costunbres de los romanos pontifiçes, cerca de los quales valie mucho el poder e las dadivas de quienquiera que darlas pudiese" (Crónica anónima de Enrique IV de Castilla, 1454-1474. Ediciones de la Torre, Madrid. 1991, p. 160)

"André SEGAL, A propos de l'attrait des femmes pour les clergues, "L’érotisme au Moyen Agge. Etudes présentées au Troisième colloque de I'Institut d’études médiévales". Bruno Roy, dir.. Les éditions de l'Aurore, Quebec. 1977. pp. 175-178

15-Madeleine Jeay, Sur quelques contumes sexuelles du Moven âge. "L’érotisme au Moyen Age. Etudes présentées au "Troisième colloque de I'Institut deétudes médiévales". Bruno Roy. dir.. Les éditions de l'Aurore. Quebec. 1977. pp. 145-146.

${ }^{153}$ Guy DEVAlLLY. L'encadrement paroissial: rigueur et insufisssance. "Cahiers de Fanjeaux". 11 (Toulouse, 1976). p. 414. 
muralla i a Castella s'adverteix que "judio, dona y hombre con corona, jamás perdona" 154 .

Atesa la global cosmovisió cristiana i la creixent vivència religiosa en uns tons aristotelicorealistes, les característiques dels eclesiàstics, ultra la jocositat inherent, són vistes amb temor pel dany, a voltes irreparable, que poden infringir arran de la negligència en unes actuacions salvífiques que indefugiblement resten exclusivament en les seves mans. Les situacions més greus es viuen en els reiterats períodes d'interdicció, en què "divina officia non presumerent celebrare", raó per la que "no sich canten misses ne matines, la qual cosa és fort enujosa e greu als ciutadans", a més que, segons la legislació eclesiàstica, "laicus tempore interdicti presumat sepelire in cimiterio alicuius ecclesie aliquem deffunctum" 155 , de la mateixa manera que, en els afectats per l'excomunió, resta vedat l'accés no sols als sagraments sinó a celebracions com els casaments dels fills. Sempre es viu de manera més intensa quan la interdicció es pronuncia "en aquest dia tant seynalat", com es diu a Lleida el 1350, en rebre-la el dia de la Mare de Déu de setembre o, també, a la Barcelona que rep la interdicció per la quaresma de 1341, amb la lesió que desencadenarà en no poder-se canalitzar les "almuynes e oracions e altres piadoses coses" pròpies d'aquests dies. Ultra aquest dany espiritual, també dol, com és lògic en una societat de creixent gust per la forma i la teatralitat del sentiment, que a causa de la punició no es puguin celebrar processons tan vistoses "axí com era acostumat", de manera destacada, en dies com el Corpus, segons es diu a la Barcelona de 1370 .

Coherentment, les autoritats locals tractaran d'evitar la interdicció, fins i tot bloquejant l'accés als campanars perquè no pugui ser proclamada, com es fa a Perpinyà el $1369^{156}$. Un cop pronunciada, són els mateixos governants locals els qui trameteran representants tant devant del bisbe com,

\footnotetext{
${ }^{154}$ José María MonSalvo. Teoria y evolución de un conflicto social. El antisemitismo en la Corona de Castilla en la Baja Edad Media. Siglo Veintiuno editores. Madrid. 1985. p. 122.

${ }^{155}$ Johannes VINCKE, Documenta selecta mutuas civitatis arago-cathalannicae et Ecclesiae relationes illustrantia. Biblioteca Balmes, Barcelona, 1936, p. 140; AHCBr. Fons municipal, I-B, llibre 15, fol. 51r; Tomàs NogUer I Musqueras; Josep Maria PONS I GURI. Constitucion. sinodals de Girona de la primera compilació, "Recull d'Estudis d'Història Jurídica Catalana". II, Fundació Noguera, Barcelona, 1989. pp. 139-140.

${ }^{156}$ D. M. J. HENRY, Histoire de Roussillon comprentunt I'histoire du Royanme de Majorque. Laffite Reprints. Marseille. 1974 (Paris. 1835), p. 381.
} 
sobretot en ciutats importants, del rei perquè hi intercedeixi ${ }^{157}$. La intercessió reial també és cercada davant de l'augment de les excomunions personals, segons es viu a Puigcerdà el $1359^{158}$.

De fet, tot i que la gran extensió de l'excomunió afecta entre 1338 i 1339 a personatges com el comte de Prades per raó d'un matrimoni considerat incestuós fins a ser-ne redimit ${ }^{159}$, la condició d'excomunicat manté una càrrega de desprestigi social. Tant aquest sentit com l'evidència que entre el comú de la població hi ha molts excomunicats, es reflecteix quan en diferents corts judicials, després de rebre una declaració, per tal d'aquilatar el valor de les paraules es sol preguntar al testimoni, entre altres coses, "si est instructus vel suburnatus, periurus vel eccomunicatus".

Les característiques morals dels clergues i els inconvenients i danys que se'n deriven perfilen una actitud ben contrària a les seves persones. En esclatar la tensió amb facilitat se'ls insulta - "muyren, muyren los bacallars de cugots!" es crida al Corpus de 1370 a Barcelona- o s'assalta el palau del bisbe d'Elna tot cridant "a fogo!, a fogo!". Esdevé, de fet, un lloc força comú en la historiografia parlar d'un anticlericalisme a tot l'Occident baixmedieval ${ }^{160)}$.

Els mendicants, que hauran de pledejar amb el clergat ordinari al ser entesos per aquests com intrusos en minvar les donacions i serveis de les parròquies, sintonitzen molt millor en una societat on demanen tarifes litúrgiques força més reduïdes i presten una col-laboració prou evident en les tasques municipals. Tanmateix, la davallada moral de la segona meitat del segle XIV ${ }^{101}$, propicia que també ells siguin objecte dels acudits populars, sovint lligats a la indolència i l'afany pel sexe o les almoines ${ }^{162}$.

Bé que de manera globalment minoritària, en altres ocasions la ruptura no sols s'expressa vers els clergues sinó de cara a la mateixa creença religiosa. Entre els testimoniatges encerclats com a herètics sovintegen

\footnotetext{
${ }^{159}$ AHCP. Llibre del Consell 2. fol. 6his v: AHCBr. Fons municipal I-B. llibre 15, fol. 51r.

${ }^{158}$ AHCP. Llibre de Provisions Reials 1.1. fol. $21 \mathrm{r}$.

${ }^{15 "}$ ADM. Sección Prades, legajo 1. núm. 4.

${ }^{10(1)}$ Hom parla respecte de the problem of "anticlericalism" (R. N. SWANSON. Religion and Derotion in Europe, c. 1215-c. 1515. Cambridge University Press. Cambridge. 1995. p. 249), fins al punt deafrontar-ho globalment: P. A. DYKEMA and H. A. OBERMAN, eds. Anticlericalism in late medieval and early modern Eirrope. Leiden. New York. Cologne. 1993.

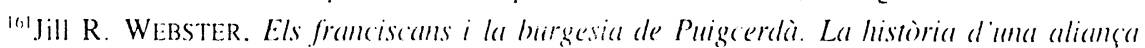
medie'val. "Anuario de Estudios Medievales". 26 (Barcelona, 1996). pp. 160-161.

16-José Estiban. Reframerer anticlerical. Vosa. Madrid. 1994. pp. 24-32.
} 
expressions ben properes a l'ateisme, com la de l'home que a la Cerdanya d'inicis del segle XIV "va declarar davant de testimonis que no hi havia Déu ni ànima en l'home, només sang"16.3.

\section{RÉSUMÉ}

Au quatorzième siècle, la relation entre l'Église séculaire et le monde qui l'entoure est caracterisée par le conflit: la difficile intégration de ses positions dans la société urbaine, le besoin de défendre son propre espace devant la croissance du pouvoir royal, les nouvelles attitudes envers la crise morale et économique, et, finalement, l'image contradictoire offerte face à une société qui avance vers l'anticléricalisme.

\section{SUMMARY}

The fourteenth century was characterized by conflict between the Church and its environment: the incompatibility of its tenets with the life of urban society: the need to defend its own spheres of jurisdiction against the burgeoning royal power: new attitudes towards the moral and economic crisis: and finally the contradictory image that the Church offered to a society that was advancing towards anti-clericalism.

\footnotetext{
${ }^{16.3}$ Antoni PLADEVALL. El deganat de Cerdanya. El panorama religiós de la Cerdamya a principis del segle XIV, "I"r Congrés Internacional d’història de Puigcerdà" (juliol 1977), Institut d'Estudis Ceretans, Puigcerdà, 1983, p. 138.
} 